\title{
The role of environmental management systems in Hungary - Theoretical and empirical insights ${ }^{*}$
}

\author{
Gyorgy Malovics, Gabor Racz, Sascha Kraus**
}

Environmental and social aspects, Corporate Social Responsibility (CSR) and Environmental Management Systems (EMS) play an increasingly important role in Western societies. Their role in the Hungarian business sphere has been growing continuously since the removal of the Socialist regime at the end of the 1980s. CSR and EMS are strengthened by two main factors: Hungary's EU accession and the German-oriented Hungarian economy. Recognizing this process, the aim of this paper is to give an insight to the reader regarding the present state of environmentally-conscious company management in Hungary, taking a strategic approach, on the basis of empirical research carried out at the end of 2004.

Umweltbezogene und soziale Aspekte, Corporate Social Responsibility (CSR) und Environmental Management Systems (EMS) spielen eine zunehmend wichtige Rolle in den westlichen Gesellschaften. Ihre Rolle in der ungarischen Wirtschaft hat ebenfalls seit dem Ende des sozialistischen Systems Ende der 1980er Jahre kontinuierlich zugenommen. Dieser Prozess wird durch zwei wesentlichen Faktoren bestärkt: Ungarns EU-Beitritt und die Deutschlandorientierte ungarische Wirtschaft. Vor diesem Hintergrund versucht dieser Beitrag, dem Leser auf Basis einer empirischen Untersuchung von Ende 2004 einen Überblick über den derzeitigen Stand des umweltorientierten Managements in Ungarn aus strategischer Sicht zu geben.

Key words: environmentally conscious corporate management, EMS, strategy, competitiveness

* Manuscript received: 31.10.05, accepted: 19.02.07 (1 revision)

** Gyorgy Malovics, Ass. Prof, University of Szeged, Hungary. Main research areas: Invironmental management, corporate social responsibility, business and sustainability and industrial ecology. Corresponding address: gymalovics@jgytf.u-szeged.hu

Gabor Racz, Ph.D Candidate, University of Pecs. Main research areas: Invironmental management and invironmental economics.

Sasha Kraus, Ass. Prof., University of Oldenburg, Germany. Main reseach areas: Strategic management, entrepreneurship and SME management. 


\section{Introduction}

Environmental management is gaining greater importance as opposed to classical environmental protection. One of the major reasons for this is that customers, business partners, and environmental jurisdiction seem to place a growing environmental pressure on companies. In Hungary, this process is strengthened by two main factors: recent EU accession and the German-oriented Hungarian economy.

Although academic researchers still disagree whether green consumerism ${ }^{1}$ is gaining relevance, industry seems to think so. After analyzing the results of a wide range of empirical research carried out about corporate motivations regarding environmental investments, regulations and consumer pressure were found to be the most important drivers for such investments (Hall 2001). A recent study from Norway found that consumer demand plays the most important role, while until the mid-1990s, government regulation put the most external pressure on company environmental performance (Doonan et al. 2005). Other empirical research also supports the emergence of "green consumers" (Gerbens-Leenes et al. 2003; Kumar/Malegeant 2005). Reports from the World Business Council on Sustainable Development (WBCSD) give evidence for the view that business success cannot be separated from sustainability efforts; they are becoming increasingly common in international business life (WBCSD 1996a-d, 1997a, 1998a-b, 2000a-b, 2002a-b, 2003a, 2004a, 2005a-e, 2006a-c).

Banks and insurance companies are increasingly developing serious environmental expectations towards firms. Also, the environmental sensitivity of the public and the media has increased. If companies do not want to lose market share, they need to take these facts into consideration.

A variety of developments can be seen in industry regarding environmental protection and measures. There are several industries, such as the chemical industry, where environmental measures mean a definitive competitive advantage. The expense of classical environmental protection technologies (e.g. equipment for reducing end-of-pipe emissions) have grown significantly during the last years. Environmental actions or certificates often mean an advantage in the competition for development support. The motivation of employees has also changed, i.e. more and more workers feel increasingly responsible towards the environment. Together with other factors, the "polluter pays" principle also forces companies to think about measures ranging from consumption reduction to end-of-pipe solutions.

1 According to approximations, the global demand for green products reached an amount of USD 545 billion in 2002. Although this is only 1\% of the whole world economy, this market is rapidly growing. Green procurement also gains even more importance in the governmental sector, whose procurement activity reaches about 10 to $25 \%$ of the GDP in the developed world (Renner 2004). 
Because of this development, a new notion has emerged: environmental management, i.e. planning, organization, realization and control of each environmental protection activity of the company in order to realize the environmental-oriented corporate policy (Winter 1997). Environmental management is a concept, a conviction and a form of conduct with the basic goal of securing that the company's activity does not endanger human health and the environment. One of these approaches is environmental management systems (EMS), which contributes to corporate success through instruments like the minimization of waste, cleaner technologies, end-of-pipe technologies, etc. In practice, EMS emerges through standards, instruments and measures. Several of them are generally accepted and used internationally, e.g. the single standards of ISO 14000, whereas others are used and interpreted differently depending on the country. Some measures and instruments have only been developed in certain countries or companies.

While an EMS certificate can never be a guarantee for a company to produce goods or provide services in an environmentally-conscious way, it can at least provide a framework that helps to initiate the necessary modifications. This means a serious leap forward in the realization of environmental management.

This article intends to provide an overall picture of the present state of corporate environmental protection from a strategic approach ${ }^{2}$. The coherent empirical study about EMS in Hungary mainly deals with the following three topics:

1. Why do companies introduce EMS?

2. To what extent do EMS contribute to economic success?

3. How do companies see the internal and external circumstances of corporate environmental protection?

2 Organizational theories dealing with the social and envionmental aspects of business. Organizations can be divided into two categories (Kovács 2000): The advocates of the strategic approach admit that business organizations have to care about environmental and social aspects of their activities because of the requirements set up by the different corporate stakeholders. However, they analyze such aspects that are only subsumed to business interests, examining how these environmental and social activities are able to contribute to future corporate growth and economic success (for more details see Savage et al. 1991; Freeman 1994; Clarkson 1995; Goodpaster 2003; Wilson 2003; Whysall 2004). Contrarily, according to the system-oriented approach, organizations are considered as parts of larger systems (i.e. the natural, social and the economic systems) when analyzing them. This means that the results of their activities should be judged on the basis of their effects on these larger systems. 


\section{Development of hypotheses}

\subsection{EMS in Hungary}

From 1998 to 1999, the International Network of Environmental Management (INEM) conducted a survey on the current state of environmentally-conscious corporate operation. It came to the result that Hungarian companies were already committed to environmental management: the number of ISO 14001certified companies was 60 at that time, with Hungary ranking $28^{\text {th }}$ in the international hierarchy on the basis of the number of certified companies. Comparing the number of certified companies to their respective country's GDP, Hungary came in $3^{\text {rd }}$ place behind Sweden and Denmark, being ahead of e.g. Germany, Japan and the UK, all "strongholds" of ISO 14001 (Pataki-Tóth, 1999).

In recent years, the number of EMS-certified companies in Hungary has grown rapidly, reaching more than 800 at the beginning of 2005. At the same time, a consistantly high amount of Western capital has flown to Hungary since the early 1990s. The reasons for Hungary being such an attractive target for Western capital are - among other factors - that certain elements of market relations have already been present in the country due to the 1968 economic reform (the so-called New Economic Mechanism), the introduction of the twotier bank system, and the opening of the Hungarian stock exchange in the 1980s (Balaton 2002). After privatization, a significant amount of foreign direct investment (FDI) was invested in Hungary: Foreign investors owned more than $45 \%$ of the called-up share capital of all Hungarian enterprises and $70-75 \%$ of the Hungarian stock exchange capital in 1997 (Kovács 1999). As a result of this process, a basic change appeared in the profile, structure and the applied technology of the firms through the 90 s. By $2000,80 \%$ of the Hungarian export was produced by companies of foreign property (Balaton 2002).

It can therefore be assumed that large Western companies with existing environmental management standards prescribe certification to their Hungarian suppliers as well when investing in Hungary. The following hypothesis can be postulated:

Hypothesis 1: The high rate of EMS in Hungary is caused by the high rate of Western companies being present in the country. EMS spread mainly among them.

\subsection{Motivation of Introduction}

According to Drechsler (2004), the four possible explanations for environmental investments are: 1) stakeholder pressure, 2) competitive positioning, 3) financial analysis, and 4) corporate social responsibility (CSR). The first three are business motivations, which may appear simultaneously, and 
are usually stronger in extent than responsibility (Fryxell/Szeto 2002; Kwon et al. 2002; Fryxell et al. 2004; Biondi et al. 2000). According to the director of the Hungarian Business Council for Sustainable Development, Máté Kriza, the main motivator of the business sector is profit, and the management of a sustainable company regards CSR and EMS as a business chance. Bertrand Collombs, the president of the WBSCD, considers CSR as a philosophy vital for successful business (Figyelö 2005) ${ }^{3}$. Based on these facts, the following hypothesis is established:

Hypothesis 2: $\quad$ Most Hungarian companies introduce EMS for economic and competitive reasons.

\subsection{EMS and Corporate Success}

\subsubsection{Microeconomic theory}

Academic literature regularly uses an inverse U-shaped curve to describe the relationship between environmental management and economic success (Wagner/Schaltegger 2004).

Figure 1. Possible relations between corporate environmental protection and economic success

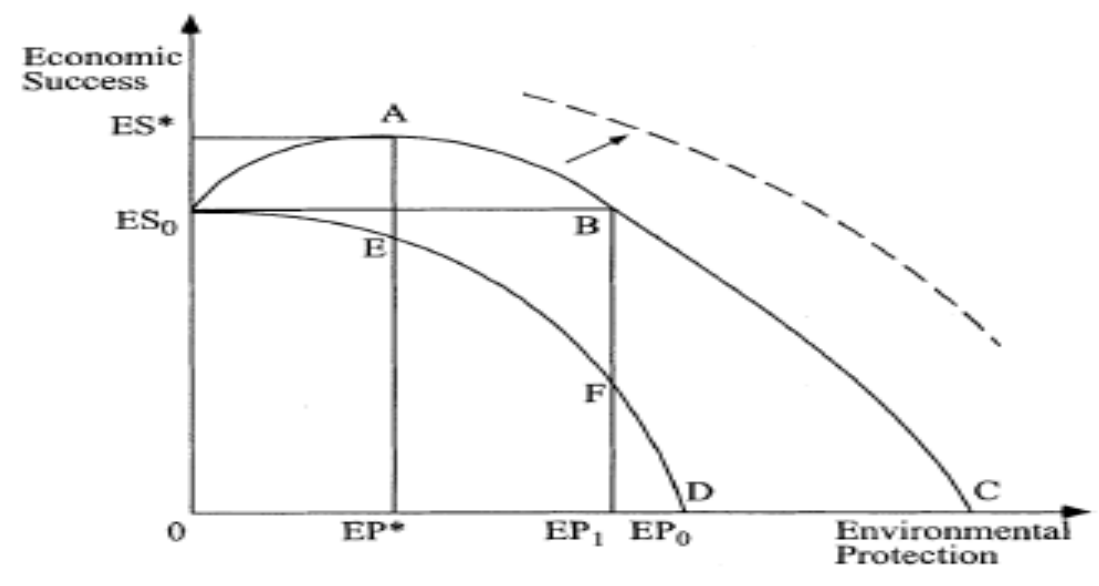

Source: Schaltegger and Synnestvedt 2002

Curve D shows the traditional view of corporate environmental protection. It suggests that there is a trade-off between environmental and economic performance - moving right on this curve means improved environmental, but worse economic performance.

3 Another sign underlying the aforementioned facts is that even more companies publish their corporate sustainability reports: 487 of such reports were published in 2001, only 194 in 1995, and a mere 7 in 1990 (Funk 2003). 
Curve $\mathrm{C}$ suggests that by overfilling the level of environmental legislation, it is possible to gain both economic and environmental benefits - moving e.g. from $\mathrm{ES}_{0}$ to $\mathrm{A}$. In this case, corporate environmental protection can be considered as a win-win situation.

\subsubsection{Practical results of previous empirical research}

\subsubsection{Measurement difficulties}

The practical measurement of the economic effects of environmental protection is not an easy task. There is no accepted definition of the concept (Wagner/Schaltegger 2004), which makes it hard to reveal the relationship between environmental management and financial performance. Also, most companies' accountancy systems are not able to follow the beneficial financial results of the given environmentally-conscious management instruments, while managers frequently fail to appreciate the full extent of their introduction (Evangelinos/Halkos 2002). In addition, it is difficult to get proper data on recovery periods (regarding instruments, measures and standards) because of the following limits: limited reliability of corporate costing system ${ }^{4}$ (on which these data are based), getting financial governmental aid in the introduction of the system (actual costs do not match planned costs quoted to the sponsors/political circumstances), and corporate actors (environmental experts) try to communicate their work within the company as something that saves costs rather than increases them. Monetary benefits are even harder to estimate (Freimann/Walther 2002).

Also, it is not only the environmental performance which influences the economic performance, but moreover a reciprocal relationship, i.e. companies which are already successful on the market are often the ones which apply environmental management (Schaltegger/Synnestvedt 2002). This relationship is further influenced by several factors, such as a country's regulatory regime, cultural setting, customer behaviour, the type of industries or size of companies analysed, time span etc. (Schaltegger/Synnestvedt 2002).

\subsubsection{Findings of previous empirical research}

Despite measurement problems, sustainability (the relation between economic, ecologic and social performance), especially the effects of CSR and EMS on corporate financial performance, has recently become a popular research area. One stream in EMS research states that there is a direct relation between environmental management and financial success. According to this view, it is worth integrating corporate environmental protection into corporate strategy since it is a win-win position, both in an economic and an environmental sense.

4 For more details regarding accontancy diffiulties of intangibles see Lev et al. (2005). 
Not handling environmental issues on a strategic level, but only providing patchwork solutions to problems will soon cause a serious disadvantage in competition. However, the relationship is not that obvious (Pataki 2000). For example, Vastag and Melnik (2002) raise the question if EMS really is the success story it claims to be, and why company managers are not more interested in applying it. The overall rate of companies implementing these standards in the EU is below 1\% (Evangelinos/Halkos 2002). According to empirical research carried out in the US (Vastag/Melnik 2002), there is no economically based reason to introduce EMS certification, but only "soft" reasons such as improved company reputation.

According to Salzman et al. (2005), previous investigations in the topic come to different conclusions, and there is no evidence of what effect (negative, positive or neutral) CSR and EMS have on financial performance. This is caused by the complexity of the research area and measurement, the various types of social and environmental problems, and responsibilities emerging in different geographical areas and industries. In addition, the authors assume that the inconclusiveness of results also have other reasons: the use of a various (often inadequate) measures, lack of effort to empirically test definitions and concepts, lack of significance testing and control for interaction with other variables, and inadequate sampling techniques, also due to limited data availability (Perrini 2005; Gazzola/Mella 2005).

The same is true for environmental investments (Carter et al. 1999; Wagner et al. 2004; Drechsler 2005). Nevertheless, the view that business success cannot be separated from CSR and EMS becomes increasingly accepted in practical international business life. Financial and stock exchange comparisons show that the value and index of shares of firms applying sustainable strategic approach are rendered above the average level (Figyelö 2005). Other studies show that SMEs can also benefit from EMS (Biondi et al. 2000).

The difficultly in measuring the effects of EMS on corporate financial performance is evident. Although existing research shows that economic and ecologic improvements are not necessarily conflicting, there is not an automatic unidirectional relationship between them.

\subsubsection{Strategy and performance}

One reason for this uncertainty could be that environmental management has both positive and negative financial effects (Zhu/Sharkis 2004). The introduction of environmentally-conscious measures requires initial investments, but the resulting cost savings can exceed the extra costs, which would highlight the possible importance of environmental strategy.

Wagner and Schaltegger (2004) isolated four factors of environmental competitiveness: market benefits, satisfaction and reputation benefits, 
profitability, and risk reduction. The authors examined whether the choice of an environmental shareholder value oriented corporate environmental strategy has a significant effect on the relationship between environmental and financial performance. They found that strategy choice indeed made a difference, i.e. firms with a value-oriented corporate environmental strategy experienced a positive relationship between environmental and economic goals. The authors discovered examples of positive, neutral, and negative relationships between environmental and financial performance. It seems that not the fact of being green, but the way of being green determines the links between environmental and financial performance (Schaltegger/Synnestvedt 2002). Based on these remarks, the following hypothesis can be postulated:

Hypothesis 3: Although there is no direct link between environmental management and corporate success, environmental management can contribute to the success of companies and possibly mean a real competitive advantage.

\subsection{Circumstances of Corporate Environmental Protection}

It can be assumed that CSR and EMS are motivated by market factors and may result in corporate success because stakeholders expect more and more social and environmental responsibility from companies. Since both concepts are market-driven, external circumstances - such as law requirements or consumer expectations - can determine their future application to a great extent.

Extended producer responsibility (ERP) is a potential influential future motivator which is gaining more importance. The essence of ERP is that producers are forced to take back their products in accordance with recycling or reuse requirements. The following chart summarizes existing ERP laws in various industries (Renner 2004).

Other regulations - for example that all EU vehicles must be manufactured from 85 percent recycled material when compared to their weight (Mastny 2004) - also highlight the importance of environmental management.

Besides regulation, the aforementioned "green consumers", green procurement and socially responsible investments may also play an important role. Hungarian research (Borsi 1997; Pakainé/Herczeg 1999; Németh 1999; Vágási 2000) states that green aspects in consumer decisions are also playing a more significant role in Hungary. Accordingly, the following hypothesis can be formulated:

Hypothesis 4: There are real external and internal pressures for applying environmental management in Hungary at present. 
Table 1. EPR in different countries in different industries

\begin{tabular}{|l|l|}
\hline $\begin{array}{l}\text { Production } \\
\text { area or } \\
\text { Industry }\end{array}$ & \multicolumn{1}{|c|}{ Countries applying EPR } \\
\hline Packaging & $\begin{array}{l}\text { More than 30 countries, for example Brazil, China, Czech Republic, Germany, } \\
\text { Hungary, Japan, Holland, Peru, Poland, South Korea, Sweden, Taiwan, Uruguay } \\
\text { (only concerning beverage boxes) }\end{array}$ \\
\hline $\begin{array}{l}\text { Electric and } \\
\text { electronic } \\
\text { equipment }\end{array}$ & $\begin{array}{l}\text { More than a dozen countries, e.g. Belgium, Brazil, China, Denmark, Germany } \\
\text { (only on a volunteer basis), Italy, Japan, Holland, Norway, Portugal, South Korea, } \\
\text { Sweden, Switzerland and Thailand }\end{array}$ \\
\hline Vehicles & Brazil, Denmark, France, Germany, Japan, Holland, Switzerland and Taiwan \\
\hline Vehicle tires & $\begin{array}{l}\text { Brazil, Finland, South Korea, Sweden and Taiwan. (Uruguay is planning } \\
\text { instructions on a voluntary basis) }\end{array}$ \\
\hline Batteries & $\begin{array}{l}\text { At least 15 countries, e.g. Austria, Brazil, Germany, Japan, Holland, Norway and } \\
\text { Taiwan. (Uruguay is planning instructions on a volunteer basis) }\end{array}$ \\
\hline $\begin{array}{l}\text { There are also EU regulations concerning all of these realms except the vehicle tires area. These are } \\
\text { mandatory in all 25 EU countries. }\end{array}$ \\
\hline
\end{tabular}

Source: Renner 2004

\section{The results of the Hungarian research}

\subsection{Introducing the sample}

The empirical part of this article is based on a quantitative empirical survey carried out in Hungary from October to December 2004. The mailed survey questionnaires $^{5}$ were sent to 150 EMS-certified companies on the basis of the database KÖVET-INEM Hungary (the Hungarian division of INEM). The questionnaires were sent to the environmental representatives of the companies. Valid responses were received from 91 out of all 771 EMS-certified companies in Hungary (11.8\%).

Approximately $50 \%$ of the companies in the sample are large companies (with more than 250 employees), whereas the rate of small enterprises was $20 \%$.

When excluding the companies that already specialize in environmental protection, i.e. those who could take our survey more seriously and therefore be overrepresented in the sample, the rate of small enterprises drops to $14 \%$, and the rate of large companies increases to $55 \%$.

The rate of companies who are part of a larger holding company is around $58 \%$. This supports the idea that the introduction of EMS is easier for companies of a larger size due to financial reasons (Buzás 2001).

5 Appendix 2 offers a brief overview into the structure of the questionnaire and the nature of the questions. 
Figure 2. The distribution of the sample according to corporate size

Number of employees

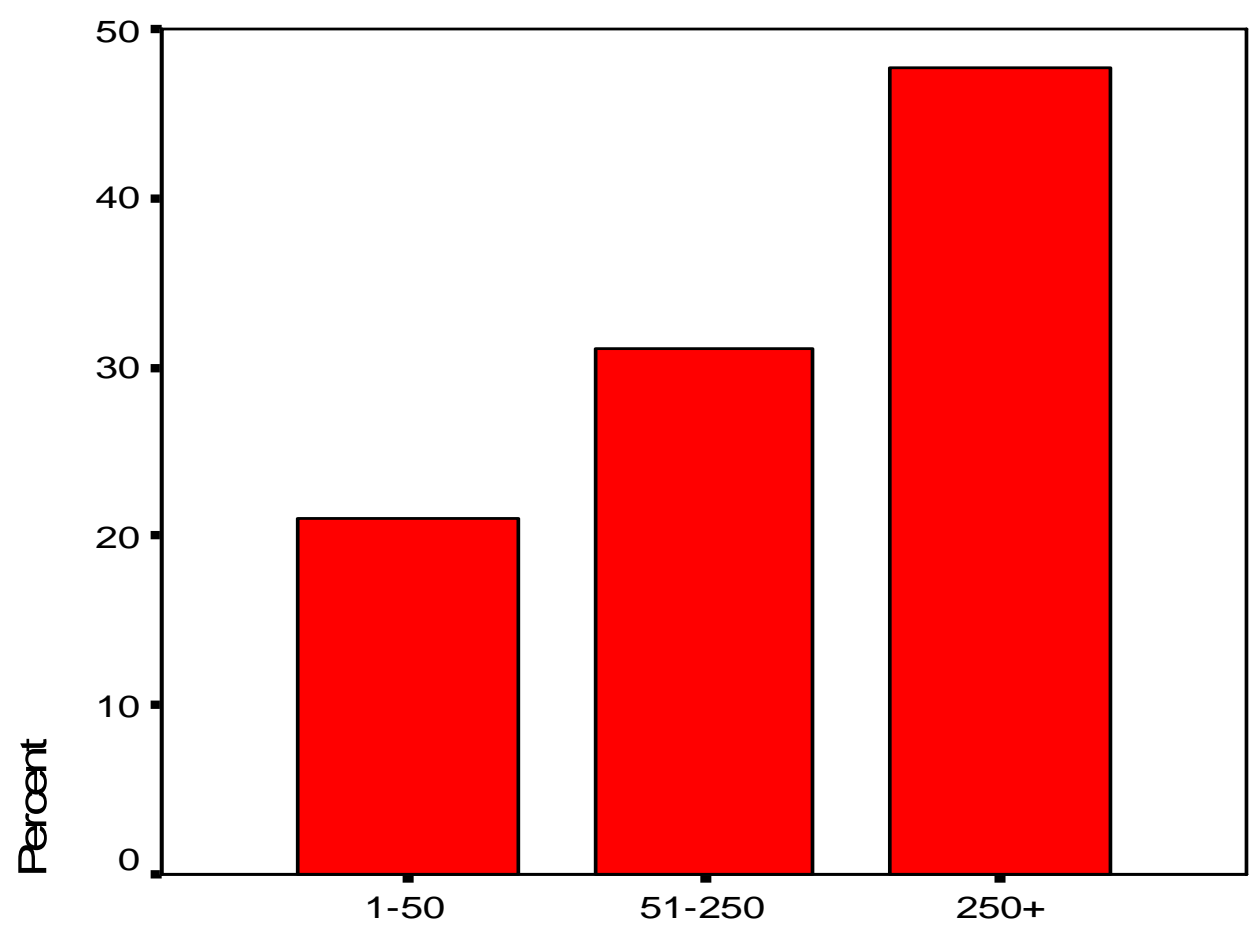

Figure 3. The distribution of the sample according to industrial composition

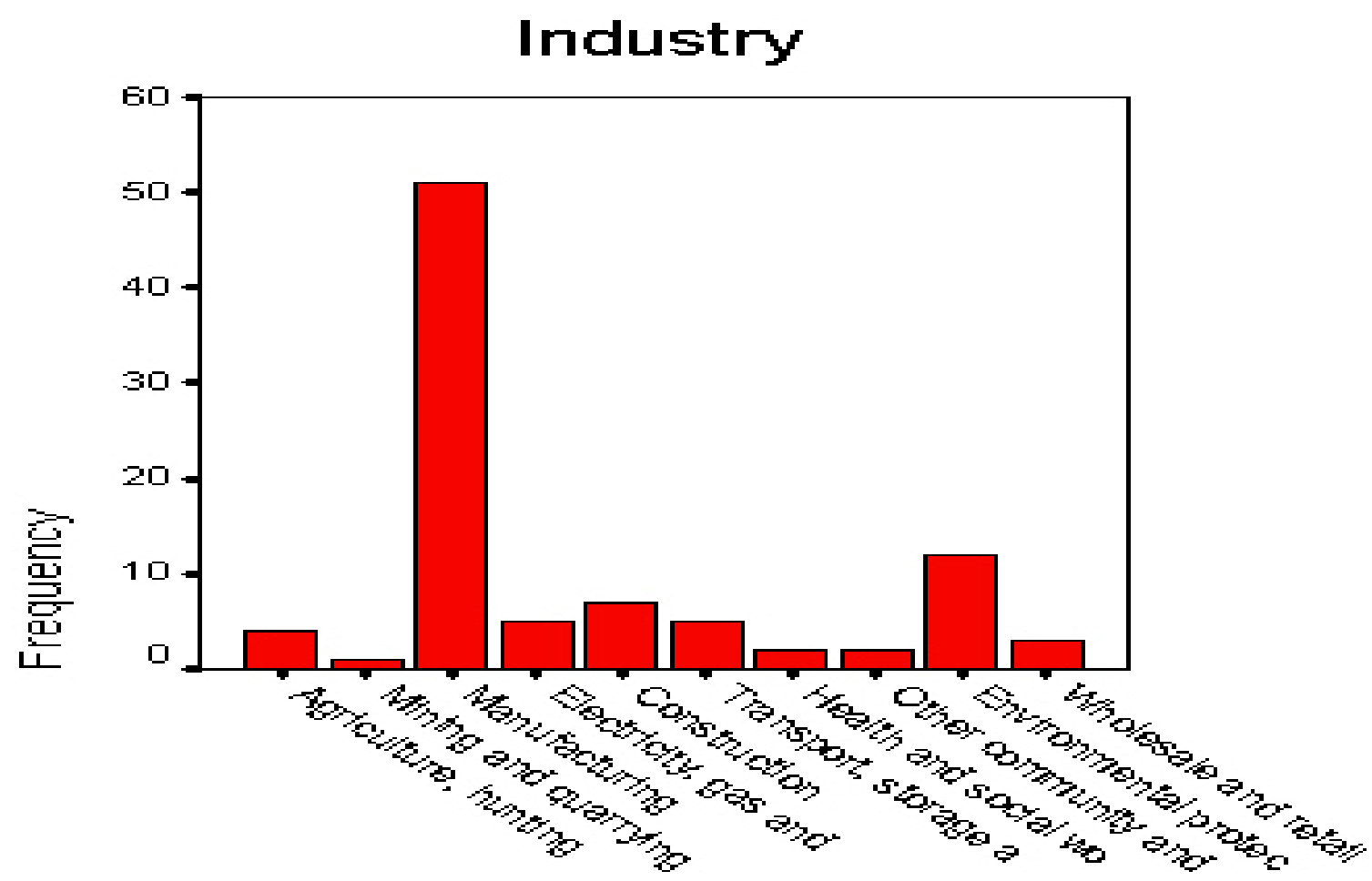




\subsection{Results}

\subsubsection{Reasons and motivations for introducing EMS}

Economic and competitive factors are dominant among the motivations for introducing EMS (see figure 4). Only $20 \%$ of the companies mention environmental protection and environmental responsibility, and most of them only in connection with economic motivators. The number of companies naming only environmental reasons is negligible. Along with economic and environmental factors, the most important motivators are the expectations of the (mostly foreign) owners, and legal requirements. Hungarian transformation research found that the transformation process is characterised by the processes that new foreign ownership meant new management methods and structures and the application of experience-based learning, so that the companies adopted the business practices of the parent company (Marosán 1996; Balaton 2002).

It is also important to emphasize that the factor "important at tenders" means the tenders of multinational companies, and not public procurement, since EMS certification does not mean an advantage in public procurement in most cases. However, foreign business tenders can be considered as extremely important motivators, which has several reasons. One is that the defensive strategies of the Hungarian companies at the beginning of the $90 \mathrm{~s}$ - as a result of the deep economic recession - were followed by strategies of innovation and growth; constant economic growth began in the mid-90s (Farkas/Mészáros 2002). At that time, one of the most important problems in Hungary was the access to new (Western) markets after the sudden breakdown of the former Eastern economic relationships (Marosán 1996; Balaton 2002). Also, private Hungarian companies were characterised by the experimental learning process during the transformation period, where they sought new processes, technologies and markets (Balaton 2002).

Furthermore, indirect institutional factors may also play a role in the spreading of EMS in Hungary. Hungarian transformation research came to the conclusion that following the patterns of other firms is characteristic of Hungarian enterprises: as long as older and larger firms follow successfull foreign companies, smaller and younger Hungarian enterprises often follow older and larger sucessful ones (Kovács 1999; Balaton 2002). Also, the change from bureaucratic coordination to market coordination, which occurred during the transformation process, may result in the building of different quality management systems (Adorján et al. 1996).

The question of which role environmental sustainability played for introducing EMS brought 50 valid responses. The average of the answers was 4.09 (standard variation was 1.01 ) on a five-point scale from $1=$ very low to $5=$

very high. This seems to contradict the result of the first question, where only $20 \%$ of the companies mentioned environmental reasons for introducing EMS. 
Figure 4. The frequency of mentioning the different motivators for introducing EMS

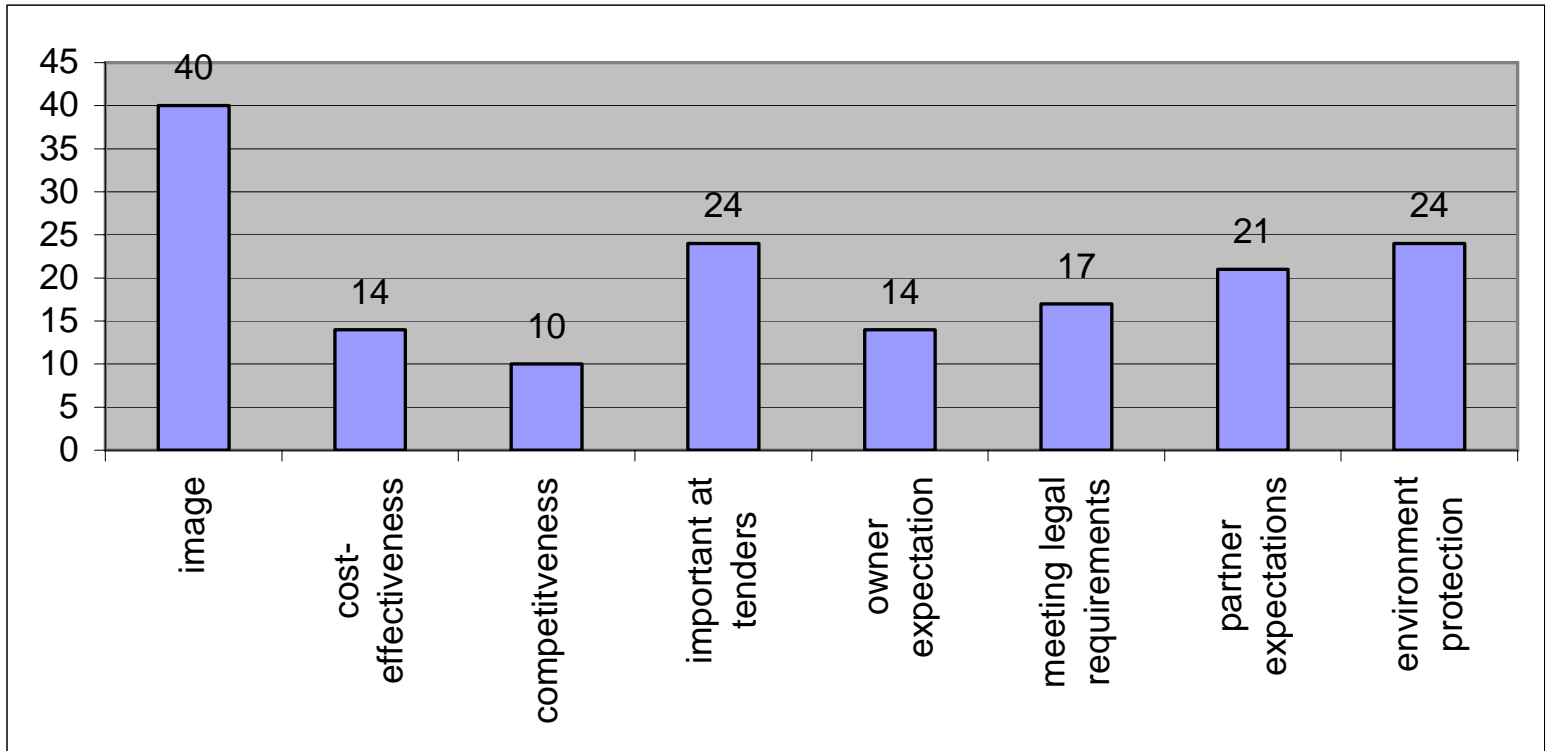

\subsubsection{EMS and economic success}

The results for the question about other environmental instruments companies use besides EMS can be grouped as follows:

1) Instruments used by most companies (more than 70\%): waste minimization (82 companies), energy rationalization (74 companies), internal trainings, motivation systems (85 companies), external communication (72 companies), and environmental indicators (72 companies).

2) Instruments used by $30-70 \%$ of the companies: cleaner technologies (60 companies), transformation of supplier systems on the basis of environmental aspects (54 companies), and renovating offices to make them more environmentally friendly (40 companies).

3) Instruments used by less than $30 \%$ of the companies: development of certified environmentally friendly products (14 companies), lifecycle analysis (10 companies), ecological bookkeeping (3 companies), ecocontrolling (17 companies), transformation of distribution systems on the basis of environmental aspects (11 companies), and environmental consultation (23 companies).

As shown, the instruments directly related to EMS are known and used by the majority of the companies. However, only a low rate of the EMS-certified companies use instruments which are not directly connected to the system.

The instruments for environmentally conscious management mentioned above and the standards themselves - are definitely held remunerative. 
Table 2. Period of recovery of environmentally conscious management tools

\begin{tabular}{|l|c|c|c|c|}
\hline \multicolumn{1}{|c|}{ Tool } & $\begin{array}{c}\text { Unable to } \\
\text { measure term of } \\
\text { refund }\end{array}$ & $\begin{array}{c}\text { Able to measure } \\
\text { term of refund }\end{array}$ & Mean & $\begin{array}{c}\text { Std. } \\
\text { Devia- } \\
\text { tion }\end{array}$ \\
\hline $\begin{array}{l}\text { Environmental management system (ISO. } \\
\text { EMAS) }\end{array}$ & 27 & 63 & 2.56 & 0.963 \\
\hline Waste minimization & 20 & 62 & 2.21 & 0.926 \\
\hline Energy rationalization & 14 & 60 & 2.1 & 0.817 \\
\hline Cleaner technologies & 13 & 47 & 2.68 & 0.726 \\
\hline Internal training. motivating system & 27 & 58 & 1.95 & 0.963 \\
\hline External communication & 31 & 41 & 1.93 & 0.959 \\
\hline $\begin{array}{l}\text { Develop. of certified environmentally } \\
\text { friendly product }\end{array}$ & 8 & 6 & 2.33 & 1.211 \\
\hline Lifecycle analysis & 4 & 6 & 2.17 & 1.169 \\
\hline Ecological accounting & 1 & 2 & 3 & 1.414 \\
\hline Eco-controlling & 7 & 10 & 2.2 & 1.229 \\
\hline Environmental indicators & 26 & 46 & 2.39 & 0.977 \\
\hline $\begin{array}{l}\text { Transforming of distribution systems on } \\
\text { the basis of environmental aspects }\end{array}$ & 2 & 9 & 2 & 0.707 \\
\hline $\begin{array}{l}\text { Transforming of transporter systems on } \\
\text { the basis of environmental aspects }\end{array}$ & 13 & 41 & 2.51 & 0.898 \\
\hline Environmental consultation & 6 & 17 & 1.82 & 0.809 \\
\hline Forming environmentally friendly offices & 15 & 25 & 2 & 1.118 \\
\hline
\end{tabular}

The period of recovery of the particular instruments has been surveyed with the help of a scale whose values referred to the different periods of recovery $(1=$ refund term of shorter than 1 year, $2=$ for $1-3$ years, $3=$ longer than 3 years, and $4=$ the instrument is not remunerative). The average of the answers has been taken as an average recovery period, providing a decent recovery time approximation. Two things can be shown in table 2:

1) The measurement of the recovery of the different instruments causes problems in a significant part of the companies.

2) Companies that are able to measure recovery consider each instrument as remunerative, most of them in the short term. The given EMS standard was also found to be remunerative - fitting the results of previous research which discovered a payback period from 1.5 to 2.5 years for EMS (Freimann/Walther 2002).

The hierachy level of EMS in the organizations is important for this research because it determines and shows the structural background of the system. According to the previous research, an independent environmental representative or manager is the best solution (Winter 1997; Buzás 2001). As the chart below shows, most of the companies apply an integrated quality manager position. Usually, job safety is also linked to these management systems. 
Figure 5. EMS in corporate structure

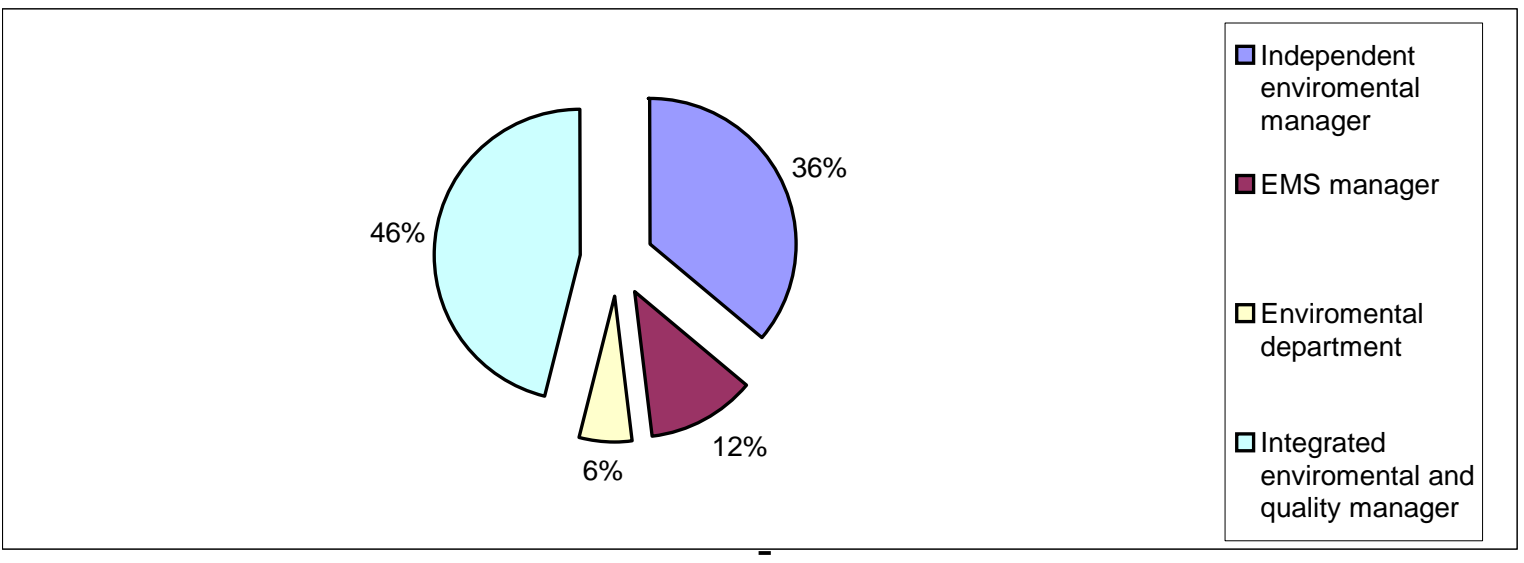

The role of environmental protection in the different functions of the companies has been measured with a five-point scale from $1=$ no importance for environmental protection to $5=$ high importance.

Table 3. The role of environmental protection in the particular corporate functions

\begin{tabular}{|c|c|c|c|c|c|}
\hline Function & $\mathbf{n}$ & Minimum & Maximum & Mean & Std. Deviation \\
\hline \begin{tabular}{|ll}
$\begin{array}{l}\text { Research and } \\
\text { development }\end{array}$ & and \\
\end{tabular} & 67 & 1 & 5 & 3.7 & 1.279 \\
\hline Purchase & 90 & 2 & 5 & 3.8 & 0.985 \\
\hline Production & 84 & 3 & 5 & 4.25 & 0.82 \\
\hline \begin{tabular}{|l|} 
Sales \\
\end{tabular} & 77 & 1 & 5 & 3.51 & 1.284 \\
\hline Logistics & 80 & 1 & 5 & 3.58 & 1.111 \\
\hline Marketing & 79 & 1 & 5 & 3.65 & 1.291 \\
\hline Accounting & 71 & 0 & 5 & 2.01 & 1.201 \\
\hline Controlling & 79 & 1 & 5 & 3.75 & 1.276 \\
\hline
\end{tabular}

It can be seen that the role of environmental protection exceeds the average in the case of most functions. The exceptions are production, where environmental protection plays a relatively important role, and accounting, where its role is unimportant.

It seems plausible to assume that the more environmental management instruments a company introduces, the more important is the role of environmental protection in the company. Therefore it has been examined whether there was a relation between the number of tools the companies introduced and the importance of environmental protection in the particular companies. However, no significant relationship between the two variables could be identified. 
It has also been examined how companies communicate their environmental consciousness through the use of a five-point importance scale from $1=$ no importance to $5=$ very important. Table 4 summarizes the results.

Table 4. Communication tools used for expressing environmental consciousness and their importance

\begin{tabular}{|l|c|c|c|}
\hline \multicolumn{1}{|c|}{ Tools } & $\begin{array}{c}\text { Number of } \\
\text { users (n=92) }\end{array}$ & $\begin{array}{c}\text { Average } \\
\text { importance } \\
\text { (n=48) }\end{array}$ & Std. Deviation \\
\hline Representing environmental politics & 90 & 4.47 & 0.786 \\
\hline Complaint management & 79 & 4.66 & 0.617 \\
\hline Information before programs & 65 & 4.29 & 0.906 \\
\hline Open days & 30 & 3.95 & 0.97 \\
\hline Notice board with advertisements & 68 & 3.88 & 0.913 \\
\hline Newsletter/internal newspaper & 46 & 4.14 & 0.655 \\
\hline Information to press & 45 & 4.15 & 0.967 \\
\hline Environmental report & 53 & 4.39 & 1.031 \\
\hline Inhabitant forums & 23 & 4.08 & 1.084 \\
\hline Environmental information on the products & 19 & 4.8 & 0.422 \\
\hline Environmental information in advertisements & 33 & 4.6 & 0.598 \\
\hline Internet & 67 & 4.11 & 0.875 \\
\hline
\end{tabular}

There are two main channels through which a company can reach its consumers most effectively: advertisements, and environmental information on the products. Still, only a few companies use them. This situation may have two different reasons:

1) Most of the firms in our sample do not appear on the market with their own products - they are only suppliers of large companies - so these types of communication are not important for them.

2) Most of the companies do not consider communicating their environmental consciousness to the public as an important task. They do not consider environmental protection an important factor in consumers' buying decision process.

A company's relationship to other environmental organizations, environmental authorities and self-government are also part of corporate communication. From this aspect, the surveyed companies can be divided into three different groups: companies already having a close partnership in different areas (group 1), companies intending to build a relationship beyond the requirements of the regulations (group 2), and companies only having relationships that meet the requirements of the regulations (i.e. mainly providing the necessary data) (group 3). Most of the interviewed companies belong to group 3. 
Figure 6: Relationship with environmental organizations and authorities

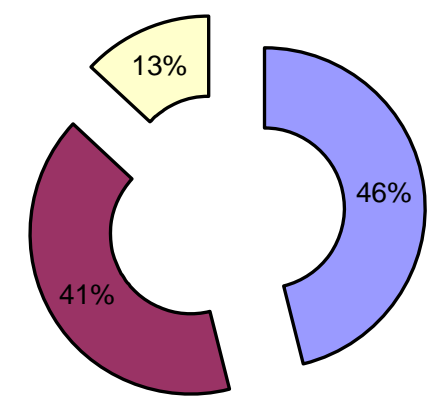

口Data providing

$\square$ Relationship beyond the requirements

口Close partnership

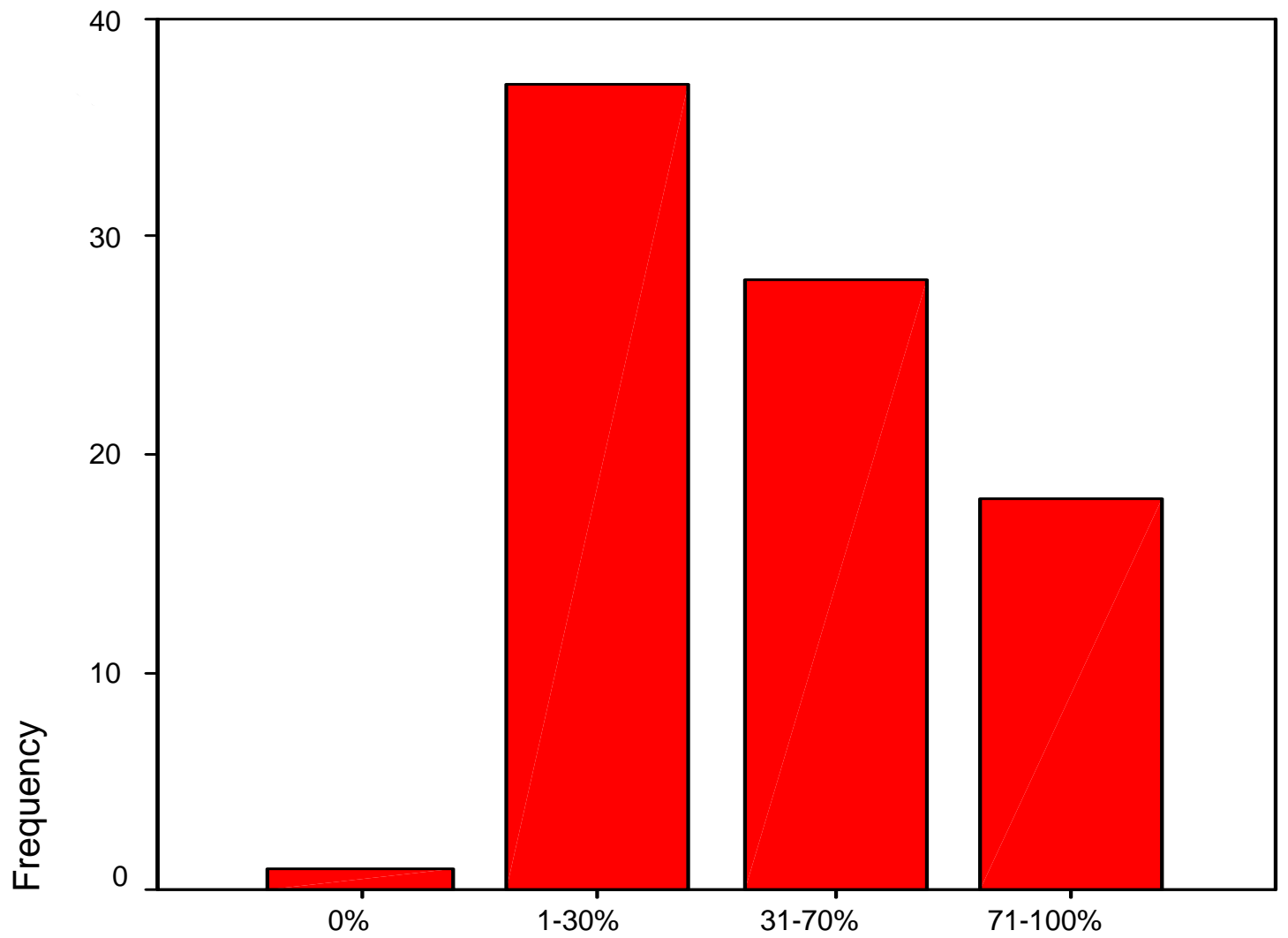

The following figure shows the opinions of the companies about environmental protection as a success factor.

As figure 7 shows, approximately $21 \%$ of the companies consider environmental protection very important for corporate success, whereas $45 \%$ do not see an important effect. Leaving out the companies belonging to the environmental protection industry, the rates change to $12 \%$ and $55 \%$.

The received answers about the particular corporate success factors harmonize with the chart above. The firms valued the effect of environmental protection on the different success factors with a five-point scale from $1=$ environmental 
protection having no positive effect on the given factor and $5=$ having a very strong positive effect. The companies consider the effect of environmental protection relatively important concerning only corporate image (3.79 on average). These results are similar to other studies where managers mentioned overall image improvement as an effect of EMS, but only slight positive concrete market effects (Freimann/Walther 2002). Also, according to the study of Evangelinos and Halkos (2002), the most important opportunity rising from environmental consciousness is increased company image.

It is a sign of consistency between the companies that there is a significant correlation (on a $1 \%$ uncertainty level) between:

- the effect of environmental protection on each of the eight success factors (see table 4) and on corporate success (see figure 3), and

- the effect of environmental protection on the average of the eight success factors on corporate success.

Table 5. The effect of environmental protection on the particular corporate success

\begin{tabular}{|l|c|c|c|c|}
\hline \multicolumn{1}{|c|}{ Success factor } & $\begin{array}{c}\text { All companies except } \\
\text { companies in the } \\
\text { environmental } \\
\text { protection industry }\end{array}$ & \multicolumn{2}{c|}{ All companies } \\
& $N$ & Mean & $N$ & Mean \\
\hline Competitiveness & 72 & 3.44 & 81 & 3.5432 \\
\hline Image & 74 & 3.88 & 85 & 3.9647 \\
\hline Market share & 68 & 2.71 & 79 & 2.9114 \\
\hline Profit & 66 & 2.23 & 77 & 2.4805 \\
\hline Quality & 75 & 3.45 & 85 & 3.5882 \\
\hline Satisfaction of managers and employees & 76 & 3.29 & 86 & 3.3837 \\
\hline Opening a new market segment & 69 & 2.8 & 78 & 2.9872 \\
\hline Cost reduction & 74 & 3.04 & 85 & 3.1294 \\
\hline
\end{tabular}

\subsubsection{Internal and external circumstances of environmental protection}

In the last part of the questionnaire, companies evaluated statements connected to the internal and external circumstances of environmental protection on a fivepoint Likert scale.

Environmental protection is widely considered as a factor improving competitiveness. Although there is no resistance to EMS within the organizations, there are also negative tendencies. The companies think that the level of demand for environmentally friendly products is quite low, that environmental legislation is immature, and distribution channels are not cooperative enough for the privileged sales of environmentally friendly products. 
Table 6. Internal and external circumstances of environmental protection

\begin{tabular}{|l|c|c|}
\hline Circumstances & $\mathbf{N}$ & Mean \\
\hline Asserting environmental aspects reduces competitiveness & 89 & 1.7 \\
\hline The demand for environmentally friendly products is not satisfactory & 83 & 3.71 \\
\hline The technical circumstances of environmental protection are immature & 86 & 3.05 \\
\hline $\begin{array}{l}\text { Environmental developments have a disadvantageous effect on the cost structure of } \\
\text { production }\end{array}$ & 87 & 2.64 \\
\hline $\begin{array}{l}\text { Eco-marketing does not offer enough opportunities for taking advantage of the } \\
\text { competitive advantages }\end{array}$ & 68 & 3.13 \\
\hline $\begin{array}{l}\text { There is a resistance in the company against EMS } \\
\text { Environmental legislation is not straightforward enough }\end{array}$ & 86 & 2 \\
\hline $\begin{array}{l}\text { Distribution channels are not cooperative enough with the privileged sales of } \\
\text { environmentally friendly products }\end{array}$ & 72 & 3.71 \\
\hline
\end{tabular}

\subsubsection{Strategy and success}

Dividing the interviewed companies into two clusters according to their environmental consciousness (see table 7), about $52 \%$ of the companies can be classified into group 1 (environmentally conscious companies), and 48\% into group 2. Ten out of the eleven companies of the environmental protection industry belong to group 1 .

It becomes obvious that the more environmentally conscious group 1 places more emphasis on environmental protection in each function. Also, these companies consider the effect of environmental protection on corporate success significantly higher. On average, they also introduce more instruments of environmentally conscious management than the companies of the other group.

\section{Discussion of results}

H1: The hypothesis that the high rate of EMS in Hungary is caused by the high rate of Western companies within the country could neither be confirmed nor negated. However, there are facts that show that foreign capital has a great importance in the spread of EMS in Hungary:

- $26 \%$ view the expectations of (mainly foreign) business partners as a motivator for introducing EMS,

- $15 \%$ view the expectations of (mainly foreign) owners as a motivator.

$\mathrm{H} 2$ : The hypothesis that the majority of Hungarian companies introduce EMS for economic and competitive reasons could be confirmed. The companies mainly viewed economic factors (e.g. improved image, cost-effectiveness or improved competitiveness) as motivators for the introduction of EMS. 
Table 7. Groups of companies on the basis of their environmental consciousness

\begin{tabular}{|c|c|c|c|c|c|c|}
\hline \multicolumn{7}{|c|}{ Final Cluster Centers } \\
\hline & \multicolumn{3}{|c|}{$\begin{array}{l}\text { All companies except } \\
\text { environmental protection } \\
\text { industry }\end{array}$} & \multicolumn{3}{|c|}{ All companies } \\
\hline & 1 & 2 & $\begin{array}{l}\text { Difference } \\
\text { between } \\
\text { final cluster } \\
\text { centers }\end{array}$ & 1 & 2 & $\begin{array}{c}\text { Difference } \\
\text { between final } \\
\text { cluster centers }\end{array}$ \\
\hline \multicolumn{7}{|c|}{ The role of environmental protection in the particular functions } \\
\hline Research and development & 4.23 & 2.96 & 1.26 & 4.24 & 3.00 & 1.24 \\
\hline Purchase & 4.26 & 3.24 & 1.03 & 4.32 & 3.23 & 1.09 \\
\hline Production & 4.42 & 3.95 & 0.47 & 4.51 & 3.98 & 0.54 \\
\hline Sales & 4.15 & 2.71 & 1.44 & 4.17 & 2.75 & 1.42 \\
\hline Logistics & 3.97 & 3.18 & 0.79 & 3.97 & 3.20 & 0.78 \\
\hline Marketing & 4.41 & 2.78 & 1.63 & 4.39 & 2.84 & 1.55 \\
\hline Accounting & 2.58 & 1.63 & 0.95 & 2.44 & 1.67 & 0.77 \\
\hline Controlling & 4.19 & 3.24 & 0.95 & 4.23 & 3.26 & 0.97 \\
\hline Average role in the company & 4.11 & 2.99 & 1.12 & 4.16 & 3.01 & 1.15 \\
\hline \multicolumn{7}{|c|}{ The role of environmental protection in environmental success } \\
\hline $\begin{array}{l}\text { How much environmental } \\
\text { protection influences corporate } \\
\text { success? }\end{array}$ & 2.97 & 2.30 & 0.67 & 3.16 & 2.32 & 0.85 \\
\hline Competitiveness & 4.35 & 2.63 & 1.72 & 4.38 & 2.64 & 1.74 \\
\hline Image & 4.23 & 3.56 & 0.66 & 4.33 & 3.55 & 0.78 \\
\hline Market share & 3.55 & 2.00 & 1.55 & 3.76 & 2.00 & 1.76 \\
\hline Profit & 2.93 & 1.64 & 1.29 & 3.22 & 1.64 & 1.58 \\
\hline Quality & 4.24 & 2.68 & 1.56 & 4.33 & 2.72 & 1.61 \\
\hline $\begin{array}{l}\text { Satisfaction of managers and } \\
\text { employees }\end{array}$ & 3.67 & 2.95 & 0.72 & 3.78 & 2.95 & 0.83 \\
\hline $\begin{array}{l}\text { Opening of a new market } \\
\text { segment }\end{array}$ & 3.82 & 1.86 & 1.96 & 4.00 & 1.86 & 2.14 \\
\hline Cost reduction & 3.69 & 2.46 & 1.22 & 3.71 & 2.48 & 1.24 \\
\hline Average role in success factors & 3.85 & 2.52 & 1.34 & 3.96 & 2.52 & 1.44 \\
\hline
\end{tabular}

Responsibility and environmental sustainability appear to be a motivator for introducing EMS in only a few of the companies. The rate of companies mentioning environmental protection as a motivator is relatively low $(20 \%)$, not to mention that hardly any companies named it on its own, i.e. without another (mainly economic) factor.

These results cannot be seen as surprising, since they only study the dealings with corporate environmental protection (Pataki 2001). Within the framework of transformation research, it is revealed that environmental protection is a measure of "becoming European" and modern for Hungarian firms, which regard the market as a necessary framework for corporate environmental protection insofar 
as environmental issues can only gain justification when they subsume corporate economic interests.

H3: The hypothesis could be confirmed that although there is no direct link between environmental management and corporate success, it can contribute to the success of companies and possibly mean a real advantage in the competition. It seems that strategy does matter. On the one hand, EMS means an advantage in the competition by the recovery of its instruments and its relatively high effect on corporate success (according to approximately $50 \%$ of the companies). On the other hand, its evaluation as a success factor in the different corporate functions is relatively low. On the basis of a cluster analysis, the companies could be divided into two groups from this aspect as well. This was shown by the higher importance of environmental protection in each corporate function and the higher number of implemented environmental management instruments (see table 7).

However, according to the previous research on own results, EMS seems to have a relatively important positive effect on corporate image (averagely 3.96 on a five-point scale). Although image can be considered as a "soft" aspect, i.e. not necessarily a strategic resource (Vastag/Melnik 2002), the situation is not necessarily that simple. Since image is a part of a company's intangible assets, it is relevant to understand how these affect corporate success for understanding the real effect of corporate environmental protection on business success. Even though it is not easy to judge how certain single resources contribute to overall corporate success due to numerous and complicated interdepencies (Marr/Roos 2005), some tendencies regarding the importance of intangibles and image may be outlined.

According to the resource-based view, "a firm's value is made up of contributions from the various components of its asset portfolio" (Sudarsanam et al. 2005:57), and a firm can be seen as a package of resources which determines the company's ability to obtain a competitive advantage (Fernström 2005). Although the resource-based view is not a homogeneous approach since it "has been formed over the last years from a variety of individual contributions having a somewhat different theoretical basis, [...] the concept derives competitive advantage from internal factors" (Moldaschl/Fisher 2004:123).

These resources can be divided into three main groups: physical, monetary and intangible assets (Augier/Teece 2005). Intangible assets are "those assets whose essence is an idea or knowledge and whose nature can be defined and recorded in some way" (Marr/Roos 2005:30), and include trademarks, patents, copyrights, regisetered designs, contracts, trade secrets, reputations and networks. Traditionally, mainly physical and monetary assets were able to deliver value, but this situation seems to have changed. Intangible assets are essential to achieve competitive advantage, and are an important source of future performance (Lev et al. 2005). In many companies, physical assets only 
represent a very small fraction of their market value, while intangibles make up a large proportion of it (Fernström 2005; Mouritsen et al. 2005). Out of the intangibles, company and product reputation - along with employee know-how - were identified in empirical studies as the most important contributors for overall corporate economic success (Marr/Roos 2005). According to the Value Creation Index (VCI), social responsibility and environmental responsibility were among the top intangible factors identified as value drivers (Funk 2003).

Based on the aforementioned facts and tendencies, EMS can be considered as a possible important contributor to corporate success because it influences one of the main important intangibles: positive image.

H4: The hypothesis that there are real external and internal pressures for applying environmental management in Hungary at present had to be divided into two parts:

1. internal circumstances (i.e. the effect of environmental protection on competitiveness and the attitude of managers and employees) can be considered favourable, whereas

2. external circumstances (i.e. demand, relevant legislation, and distribution channels) cannot.

The lack of demand for environmentally friendly products can be seen as surprising since several international companies consider consumers as being increasingly "green" in their own minds (Buday-Sántha 2002). The reason for the limited demand for environmentally conscious products in Hungary could be that that there is an intention towards a more environmentally conscious way of life, but the effects of the real consumer behaviour cannot be called "green" per se (Bebbington et al. 1994; Buday-Sántha 2002).

\section{Limitations and suggestions for future research}

The underlying research of this study was explorative in nature. Its main goal was to reveal how corporate environmental management and EMS are able to contribute to corporate economic success. The results of this empirical study suggest a need for further research in order to understand why corporate environmental management and EMS are becoming increasingly important success factors at certain companies. In order to reveal the influencing external and internal circumstances, the authors intend to carry out qualitative case studies to further understand the possible contribution of corporate environmental protection to corporate success.

Furthermore, this study was limited to companies which have already introduced EMS. As corporate environmental protection and EMS can be considered different categories, it will be important to carry out further research regarding corporate environmental protection at companies which do not apply these 
standards. To the knowledge of the authors, research of this kind has not yet been carried out in Hungary.

\section{References}

Adorján, M.(ed.) (1996): Gazdasági szervezetek az átalakulás időszakában - szereplők és stratégiák, in: Vezetéstudomány, 27, 7-8, 5-25.

Augier, M./Teece, D. (2005): An Economics Perspective on Intellectual Capital, in: Marr, B. (ed.): Perspectives on intellectual capital. Multidisciplinary insights into management, measurement, and reporting. Amsterdam: Elsevier, 3-27.

Balaton, K. (2002): Kísérlet a Közép-Kelet-Európai szervezeti változások elemzési modelljének kialakítására, in: Vezetéstudomány, 33, 5, 2-11.

Bebbington, J./Gray, R./Thomson, I./Walters, D. (1994): Accountants' attitudes and environmentally-sensitive accounting, in: Accounting and Business Research, 24, 94, 109-120.

Biondi, V./Frey, M./Iraldo, F. (2000): Environmental Management Systems and SMEs, in: Greener Management International, 29, Spring, 55-70.

Borsi, K. (1997): Zöld stratégiák, in: Marketing \& menedzsment, 31, 3, 66-68.

Buday-Sántha, A. (2002): Környezetgazdálkodás. Budapest: Akadémiai Kiadó.

Buzás, N. (2001): A környezetgazdaságtan alapjai. Szeged: JATE Press.

Carter, C.R./Kale, R./Grimm, C.M. (2000): Environmental purchasing and firm performance: an empirical investigation, in: Transportation Research Part E: Logistics and Transportation Review, 36, 3, 219-228.

Clarkson, M.B. (1995): A Stakeholder Framework for Analyzing and Evaluating Corporate Social Performance, in: Academy of Management Review, 20, 1, 92-117.

Doonan, J./Lanoiea,T.P./Laplantel, B. (2005): Determinants of environmental performance in the Canadian pulp and paper industry: An assessment from inside the industry, in: Ecological Economics, 55, 73-84.

Drechsler, C. (2005): Towards a mid-range theory of the environmental investment decision process, conference paper, EURAM 2005, Munich.

Evangelinos, K.I./Halkos, G.E. (2002): Implementation of environmental management systems standards: important factors in corporate decision making, in: Journal of Environmental Assessment Policy and Management, 4, 3, 311-328.

Farkas, M./Mészáros, T. (2002): A hazai magántulajdonú nagyvállalatok stratégiái, in: Vezetéstudomány, 33, Special Issue, 31-43.

Fernström, L. (2005): A Marketing Perspective on Intellectual Capital, in: Marr, B. (ed.): Perspectives on intellectual capital. Multidisciplinary insights into management, measurement, and reporting, Amsterdam: Elsevier, 82-95.

Freeman, E.R. (1994): The Politics of Stakeholder Theory: Some Future Directions. In.: Business Ethics Quarterly, 4, 4, 409-421.

Freimann, J./Walther, M. (2002): The Impacts of Corporate Environmental Management Systems, in: Greener Management International, 36, Winter, 91-104. 
Fryxell, G.E./Chung, S.S./Lo, C. W.H. (2004): Does the selection of ISO 14001 registrars matter? Registrar reputation and environmental policy statements in China, in: Journal of Environmental Management, 71, 1, 45-57.

Fryxell, G.E./Szeto, A. (2002): The influence of motivations for seeking ISO 14001 certification: an empirical study of ISO 14001 certified facilities in Hong Kong, in: Journal of Environmental Management, 65, 3, 223-238.

Funk, K. (2003). Sustainability and performance, in: MIT Sloan Management Review, Winter, 65-70.

Gazzola, P./Mella, P. (2005): Corporate Performance and Corporate Social Responsibility. A necessary choice?, conference paper, EURAM 2005, Munich.

Gerbens-Leenes, P.W./Moll, H.C./Schoot Uiterkamp, A.J.M. (2003): Design and development of a measuring method for environmental sustainability in food production systems, in: Ecological Economics, 46, 231-248.

Goodpaster, K.E (2003): Business Ethics and Stakeholder Analysis, in: Business Ethics Qarterly, 1, 53-73.

Hall, J. (2000): Environmental supply chain dynamics, in: Journal of Cleaner Production. 8, 455-471.

Figyelö 2005: Interviews on sustainable development and CSR with Bertrand Collomb (President of WBCSD) and Máté Kriza (Director of Hungarian Business Council for Sustainable Development) (2005): in: Figyelö, 49, 10, 60-62.

Kovács, E. (2000): A szervezetelméletek formálódása a társadalmi és az ökológiai értékek beépülése során, in: Kovász, 4, 1-4, 53-88.

Kovács, S. (1999): Külső (társadalmi - politikai) tényezők a magyar szervezetek átalakulásában, in: Vezetéstudomány, 30, 4, 2-8.

Kumar, S./Malegeant, P. (2005): Strategic alliance in a closed-loop supply chain, a case of manufacture and eco-non-profit organisation, Technovation, 26, 10, 1127-1135.

Kwon, D-M./Seo, M-S./Seo, Y-C. (2002): A study of compliance with environmental regulations of ISO 14001 certified companies in Korea, in: Journal of Environmental Management, 65, 4, 345-353.

Lev, B./Canibano, L./Marr, B. (2005): An Accounting Perspective on Intellectual Capital, in: Marr, B. (ed.): Perspectives on intellectual capital. Multidisciplinary insights into management, measurement, and reporting. Amsterdam: Elsevier, 42-55.

Marosán, G. (1996): Graboplast Rt, in: Vezetéstudomány, 27, 9, 13-22.

Marr, B./Roos, G. (2005): A Strategy Perspective on Intellectual Capital, in: Marr, B. (ed.): Perspectives on intellectual capital. Multidisciplinary insights into management, measurement, and reporting. Amsterdam: Elsevier, 28-41.

Mastny, L. (2004): Purchasing for People and the Planet, in: Worldwatch Institute (ed): State of the World 2004: Special Focus: The Consumer Society. New York: Norton\&Norton.

Moldaschl, M./Fischer, D. (2004): Beyond the Management View: A Ressource-Centered Socio-Economic Perspective, in: Management Revue, 15, 1 (Special Issue: Beyond resource based view), 122-151. 
Mouritsen, J./Bukh, P. N./Marr, B. (2005): A Reporting Perspective on Intellectual Capital, in: Marr, B. (2005) (ed.): Perspectives on intellectual capital. Multidisciplinary insights into management, measurement, and reporting. Amsterdam: Elsevier, 69-81.

Németh, P. (1999): Ökomarketing a 21. század küszöbén I., in: Marketing \& menedzsment, $33,1,41-46$.

Pakainé, K.J./Herczeg, J. (1999): Ökotudatos üzleti magatartás, in: Gidai, E./Novákym E./Tóth A. (ed): Magyarország az ezredforduló után, Budapest: MTA Jövőkutatási Bizottság.

Pataki, G. (2000): Az ökológiailag fenntartható vállalat, Ph.D. dissertation, Budapest.

Pataki, G. (2001): Az öko-modernizáció és ellentmondásai - Magyarországi nagyvállalatok zöldülése az 1990-es években, in: Kovász, 5, 1-2, 23-59.

Pataki, G./Tóth, G. (1999): Vállalati környezettudatoság - A GEMS-HU (nemzetközi felmérés a környezettudatos vállalatirányítás helyzetéről Magyarországon) eredményeinek összefoglalója. Budapest: KÖVET-INEM Hungária.

Renner, M. (2004): Moving Toward a Less Consumptive Economy, in: Worldwatch Institute (ed): State of the World 2004: Special Focus: The Consumer Society. New York: Norton \& Norton.

Savage, G.T./Nix, T.W./Whitehead, C.I./Blair, J.D (1991): Strategies for assessing and managing organizational stakeholders, in: Academy of Matiagement Executive, 5, 2, $61-75$.

Schaltegger, S./Synnestvedt, T. (2002): The link between "green" and economic success: environmental management as the crucial trigger between environmental and economic performance, Journal of Environmental Management, 65, 4, 339-346.

Vágási, M. (2000): A fenntartható fogyasztás és a környezettudatos fogyasztói magatartás, in: Marketing \& menedzsment, 34, 6, 39-44.

Vastag, G./Melnyik, S.A. (2002): Certifying environmental management systems by the ISO 14001 standards, in: International Journal of Production Research, 40, 18, 443-463.

Wagner, M./ Schaltegger, S. (2004): The Effect of Corporate Environmental Strategy Choice and Environmental Performance on Competitiveness and Economic Performance: An Empirical Study of EU Manufacturing, in: European Management Journal, 22, 5, $557-$ 572.

WBCSD (1996a): Eco-efficient leadership for improved economic and environmental performance, www. wbcsd.org.

WBCSD (1996b): Eco-efficiency and cleaner production: Charting the course to sustainability, www. wbcsd.org.

WBCSD (1996c): Trade and Environment: A business perspective, www. wbcsd.org.

WBCSD (1996d): Sustainable Production and Consumption: A business perspective, www. wbcsd.org.

WBCSD (1997a): Signals of Change: Business progress towards sustainable development, www. wbcsd.org.

WBCSD (1998a): Trade, environment, and sustainable development, www. wbcsd.org. 
WBCSD (1998b): Cleaner production and eco-efficiency: Complimentary approaches to sustainable development, www. wbcsd.org.

WBCSD (2000a): Measuring Eco-Efficiency: A guide to reporting company performance, www. wbcsd.org.

WBCSD (2000b): Eco-Efficiency: Creating more value with less impact, www. wbcsd.org.

WBCSD (2002a): Innovation, Technology, Sustainability, and Society, www. wbcsd.org.

WBCSD (2002b): Sustainable Development: A learning tool, www. wbcsd.org.

WBCSD (2003a): Sustainable Development Reporting: Striking the balance, www. wbcsd.org.

WBCSD (2004a): Mobility 2030: Meeting the Challenges to Sustainability, www. wbcsd.org.

WBCSD (2005a): WBCSD Annual Review 2004 - A decade of action and learning, www. wbcsd.org.

WBCSD (2005b): YMT 2004 - Making sustainability connections, www. wbcsd.org.

WBCSD (2005c): Driving success: Marketing and sustainable development, www. wbcsd.org.

WBCSD (2005d): Driving success: Human resources and sustainable development, www. wbcsd.org.

WBCSD (2005e): Pathways to 2050 - Energy and Climate Change, www. wbcsd.org.

WBCSD (2006a): Catalyzing Change: A Short History of the WBCSD, www. wbcsd.org.

WBCSD (2006b): Eco-efficiency Learning Module, www. wbcsd.org.

WBCSD (2006c): From Challenge to Opportunity: The role of business in tomorrow's society, www. wbcsd.org.

Whysall, P. (2000): Addressing ethical issues in retailing: a stakeholder perspective, in: International Review of Retail, Distribution and Consumer Research, 10, 3, 305-318.

Wilson, M. (2003): Corporate sustainability: What is it and where does it come from? in: Ivey Business Journal, March-April, 1-6.

Winter, G. (1997): Zölden és Nyereségesen. Budapest: Müszaki Kiadó.

Zhu, Q./Sarkis, J. (2004): Relationships between operational practices and performance among early adopters of green supply chain management practices in Chinese manufacturing enterprises, in: Journal of Operations Management 22, 3, 265-289. 